УДК 616,132.1-053.2- 071

\title{
Критерії встановлення діагнозу гіпоплазії дуги аорти у новонароджених і немовлят
}

\author{
Прокопович Л. М., Головенко О. С., Перепека І. А., Труба Я. П., Лазоришинець В. В.
}

\author{
ДУ «Національний інститут серцево-судинної хірургії імені М. М. Амосова НАМН» (Київ)
}

\begin{abstract}
Провести чітку межу між нормою та патологією для того, щоб визначити, в яких випадках наявна справжня гіпоплазія, достатньо складно. Тому з практичної точки зору принциповим питанням є відбір критеріїв, на основі яких можна говорити про клінічну і прогностично значущу гіпоплазію дуги аорти. Огляд присвячений аналізу сучасних методик визначення гіпоплазії дуги аорти і результатів хірургічного лікування даної патології.
\end{abstract}

Ключові слова: коарктація аорти, гіпоплазія дуги аорти, вроджені вади серця.

Гіпоплазія дуги аорти - це вроджена аномалія розвитку дуги аорти, що характеризується гемодинамічно значущим звуженням дуги аорти. Вважається, що в основі iï формування лежить єдиний патогенетичний механізм, пов'язаний зі зменшенням величини кровотоку по так званому «предуктальному» відділу ембріональної аорти. Незважаючи на великий інтерес до проблеми гіпоплазії дуги аорти, кількість публікацій не є великою, а в питаннях термінології та класифікації існує багато протиріч. Наразі існує низка методик, які дозволяють визначити ступінь гіпоплазії дуги аорти і планувати об'єм оперативного втручання у пацієнтів педіатричної групи.

Гіпоплазія дуги аорти може зустрічатись як в ізольованому вигляді, так і в поєднанні з іншими вродженими вадами серця (ВВC). Найбільш часто гіпоплазія дуги аорти зустрічається у новонароджених із коарктацією аорти (КА) (табл. 1). Особливістю перебігу КА з гіпоплазією дуги в ранньому віці є можливість швидкої декомпенсації вади [1-2].

Вперше КА була описана у 1760 році Morgagni. Більш точне описання даної вади здійснив Paris у 1791 році, саме він запропонував термін «коарктація» (від фран. «со-

\section{Таблиця 1}

Частота гіпоплазії дуги аорти у пацієнтів з КА

\begin{tabular}{lccc} 
Автор & $\begin{array}{c}\text { Кількість } \\
\text { пацієнтів, } \mathbf{n}\end{array}$ & Вік & $\begin{array}{c}\text { Частота } \\
\text { гіпоплазії } \\
\text { дуги аорти, \% }\end{array}$ \\
\hline Vouhe P. & 80 & до 3 міс. & 80 \\
\hline Lacour-Gayet F. & 60 & 2 тижні & 80 \\
\hline Abbruzzese P. A. & - & 40 міс. & 70 \\
\hline Dodge-Khatami A. & 271 & 5 міс & 14 \\
\hline Van Heurn L. W. & 151 & до 3 міс. & 33 \\
\hline Siewers R. D. & 102 & до 3 міс. & 32 \\
\hline Ralph-Edwards A. C. & 43 & до 3 міс. & 26
\end{tabular}

arctare» - звужувати). Перший прижиттєвий діагноз КА встановив Legrand в 1835 році. Детальний опис анатомії вади зробив у 1866 році Barie на основі патологоанатомічних досліджень 86 випадків. Перші успішні операції виконані в 1945 році у США і Швеції Crafoord i Nylin. Можливість успішного хірургічного лікування КА стала очевидною, проте віддалені результати були незадовільні через високу частоту рецидиву вади. Протягом останніх років широко обговорюється роль гіпоплазії дуги аорти як одного з факторів ризику розвитку віддалених ускладнень хірургічного лікування КА.

Низка патологоанатомічних досліджень новонароджених вказують на безпосередній зв'язок етіопатогенезу КА і гіпоплазії дуги. Згідно з гемодинамічною теоpiєю Rudolph et al. [4], гіпоплазія дуги аорти є наслідком зниження кровотоку через відділи аорти в період внутрішньоутробного розвитку. При гіпоплазії дуги аорти спостерігається значно менший діаметр поперечної дуги та перешийка, в той час як діаметр фіброзного кільця клапана легеневої артерії та ії стовбур розширені. Ще одним підтвердженням гемодинамічної теорії є зв'язок між широким застосуванням простагландину Е і збільшенням частоти вираженої гіпоплазії дуги аорти протягом останнього десятиліття. Існує висока ймовірність того, що терапія простагландином Е у новонароджених модифікує анатомічний тип гіпоплазії дуги аорти [5].

Важливим моментом під час вирішення питання об'єму операції при гіпоплазії дуги є визначення потенціалу росту дуги аорти. Нині відомо, що процес росту судини регулюється низкою ангіогенних факторів росту: судинний ендотеліальний фактор росту (VEGF), фактор росту фібробластів (FGF-2), інсуліноподібний фактор (IGF), трансформуючий фактор росту (TGF в) і деякі інші. Крім того, ріст судини детермінують фізичні фактори, наприклад, величина дотикового напруження (shear stress). Згідно з даними гістологічних досліджень, гіпоплазована частина аорти має нормаль- 


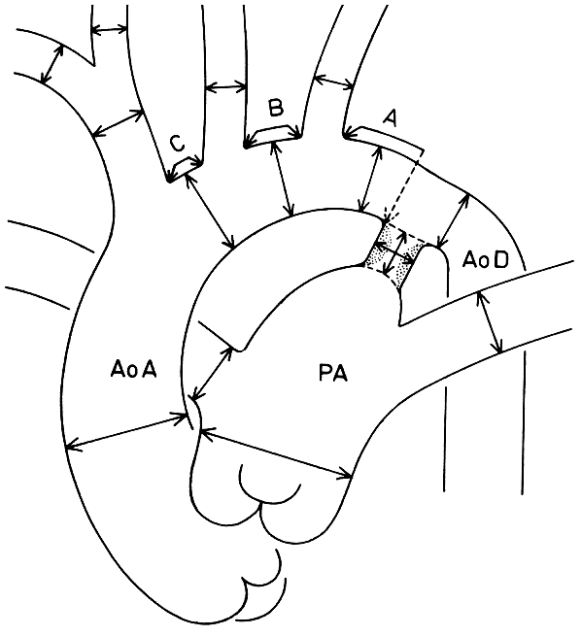

Рис. 1. Сегменти дуги аорти:

A - перешийок аорти; В - дистальний сегмент аорти; С - проксимальний сегмент аорти; АоА - висхідна аорта; РА легенева артерія; AoD - низхідна аорта

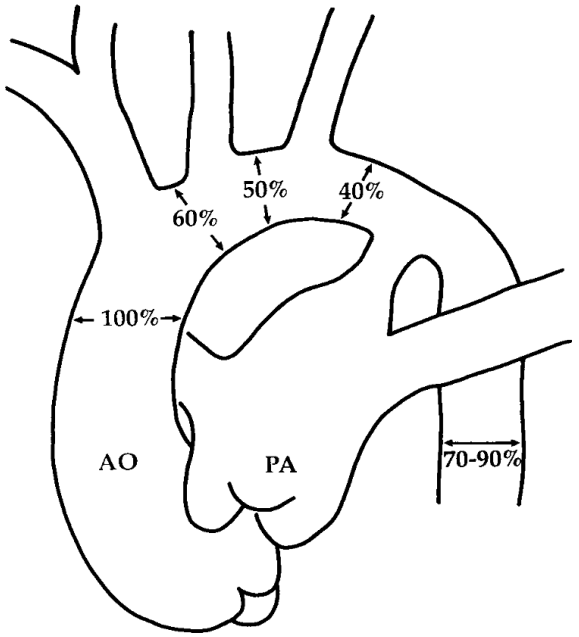

Pис. 2. Правило Moulaert для визначення гіпоплазії дуги аорти

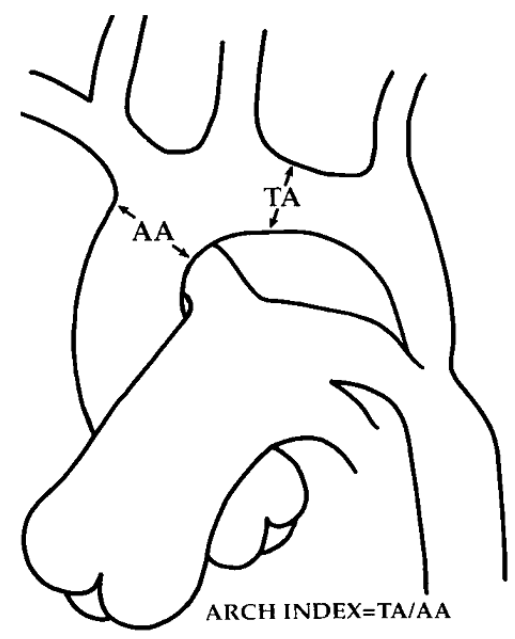

Рис. 3. Індекс дуги аорти [9]:

AА - діаметр висхідної аорти; ТА діаметр поперечної дуги аорти ну структуру і характеризується підвищеним вмістом еластичних волокон, підвищеним рівнем колагену і зниженим вмістом б-актин-позитивних клітин, що, імовірно, і призводить до порушення властивостей росту судинної стінки [6].

Анатомічно дуга аорти поділяється на три сегменти: проксимальний і дистальний сегменти поперечної частини дуги і перешийок аорти (рис. 1).

На сьогоднішній день існує декілька методів визначення гіпоплазії дуги аорти. Вперше, для визначення гіпоплазії дуги було запропоновано правило Moulaert et al. (1976), а саме: діаметр проксимальної дуги має бути більше ніж 60\%, діаметр дистальної дуги - більше ніж $50 \%$, діаметр перешийка - більше ніж $40 \%$ від діаметра висхідної аорти (рис. 2). При довжині гіпоплазованих сегментів дуги аорти 5 мм і більше прийнято говорити про тубулярну гіпоплазію дуги аорти. Наприклад, згідно з даними критеріїв, тубулярна гіпоплазія перешийка аорти наявна, коли певний сегмент довший за 5 мм, а зовнішній діаметр становить $40 \%$ або менше, ніж діаметр висхідної аорти [7]. До сьогодні багато клінік дотримується цього правила і активно застосовують його.

Друге правило, яке також активно застосовується багатьма клініками, сформульоване R. Mee et al. [8]. 3а цим правилом визначається наявність гіпоплазії дуги аорти, при якій необхідна корекція. Реконструкція дуги показана, якщо діаметр поперечної дуги (мм), виміряний при ехокардіографічному дослідженні (ЕхоКГ), в чисельному вираженні менше ваги тіла пацієнта (кг) плюс 1. Наприклад, якщо у новонародженого вагою 3 кг діаметр дуги аорти менший ніж 4 мм (тобто 3+1), дугу треба вважати гіпоплазованою, і такому пацієнту показане хірургічне розширення дуги аорти. Sakurai et al. розширили це правило, порівнявши розмір безіменної артерії та поперечної дуги, і запропонували вважати гіпоплазію наявною, якщо діаметр поперечної дуги менший, ніж розмір безіменної артерії (мм).

Для вимірювання ступеня гіпоплазії дуги аорти W. R. Morrow et al. запропонували використовувати індекс дуги аорти [9]. Даний показник був розроблений на основі морфометричного аналізу магістральних судин способом двомірної ЕхоКГ у 14 новонароджених 3 ізольованою КА і у 14 здорових новонароджених віком до 1 місяця. У пацієнтів із КА поперечна дуга і перешийок були значно меншими, ніж у контрольній групі (p $\leq 0,001)$. Крім того, діаметр клапана легеневої артерії та іiі стовбур були значно меншими у новонароджених з КА, ніж у групі здорових дітей. Ці зміни були стандартизовані за допомогою порівняльного коефіцієнта (індексу дуги аорти), який розраховувався як діаметр поперечної дуги, розділений на діаметр висхідної аорти (ARCH INDEX = TA/AA) (рис. 3). Цей показник у контрольній групі склав 0,76, а у новонароджених з КА - 0,54. Таким чином, про гіпоплазію дуги аорти можна говорити, коли індекс дуги аорти менше 0,5.

Останнім часом найбільш поширеним i, ймовірно, найбільш точним є оцінка ступеня гіпоплазії дуги аорти за визначенням відхилення діаметра дуги аорти від середнього значення вікової норми (Z-score). Дуга аорти вважається гіпоплазованою при відхиленні від стандартного значення $-2 \mathrm{Z}$ і менше. Важливо відмітити, що стандартне відхилення може змінюватися залежно від розмірів тіла [10]. Для більшості вимірювань рекомендовано проводити розрахунок Z-scores віднос- 
но площі поверхні тіла, а не росту і ваги окремо. Важливо знати, що для новонароджених нульове значення може знаходитися в межах двох стандартних відхилень від середнього значення. Наприклад, повна відсутність руху при тканинному допплері в деяких позиціях в однієї вікової групи може давати Z-scores >-2 [11]. Petterson проводив антропометричні виміри у великій групі дітей (782 пацієнти) та запропонував спеціально для немовлят і дітей раннього віку таблиці розрахунку Zscore для 21 окремої серцевої структури [12].

Висновки. Таким чином, аналізуючи результати досліджень багатьох авторів, можна зробити висновок про те, що на сьогодні існує низка методик, які дозволяють визначити ступінь гіпоплазії дуги аорти, що дає можливість планувати об'єм оперативного втручання на дузі аорти у пацієнтів педіатричної групи. Ми вважаємо, що оптимальним способом верифікації гіпоплазії дуги аорти є критерій Z-score, розрахований за фактичним ростом і нормативною масою тіла дітей.

\section{Література}

1. Hemodynamic modeling of surgically repaired coarctation of the aorta / Olivieri L., de Zŭlicourt D., Haggerty C. et al. // Cardiovasc. Eng. Technol. - 2011. - Vol. 2. - P. 288295.

2. Rosenthal E. Coarctation of the aorta from fetus to adult: curable condition or life long disease process // Heart. 2005. - Vol. 91. - P. 1495-1502.

3. Rudolph A. M. Hemodynamic consideration in the development of narrowing of the aorta / A. M. Rudolph, M. A. Hey-mann, U. Spitznas // Am. J. Cardiol. - 1972. Vol. 30. - P. 514-525.

4. Lacour-Gayet F. Hypoplastic transverse arch and coarctation in neonates. Surgical reconstruction of the aortic arch: a study of sixty-six patients / F. Lacour-Gayet, J. Bruniaux, A. Serraf et al. // J. Thorac. Cardiovasc. Surg. - 1990. - Vol. 100. - P. 808-816.

5. Siewers R. D. Coarctation and hypoplasia of the aortic arch:will the arch grow? / R. D. Siewers, J. Ettedgui, E. Pahl et al. // Ann. Thorac. Surg. - 1991. - Vol. 52. P. 608-613.

6. Machii M. Hypoplastic aortic arch morphology pertinent to growth after surgical correction of aortic coarctation / M. Machii, A. E. Becker // Ann. Thorac. Surg. - 1997. Vol. 64. - P. 516-520.

7. Moulaert A. J. Anomalies of the aortic arch and ventricular septal defects // Moulaert A. J., Bruins C. C., OppenheimerDekker A. // Circulation. -1976. - Vol. 53. - P. 10111015.

8. Coarctation of the aorta: Midterm outcomes of resection with extended end-to-end anastomosis / Kaushal S., Backer C. L., Patel J. N. et al. // Ann Thorac Surg. 2009. - Vol. 88. - P. 1932-1938.

9. Quantitative morphology of the aortic arch in neonatal coarctation / Morrow W. R., Huhta J. C., Murphy D. J. et al. // Am Coll Cardiol. - 1986 Sep. - Vol. 8 (3). - P. 616620 .

10. H. Chubb, J. M. Simpson. The use of Z-scores in paediatric cardiology / Ann. Pediatr. Cardiol. - 2012. - Vol. 5 (2). P. 179-184.

11. Impact of cardiac growth on Doppler tissue imaging velocities: a study in healthy children / B. W. Eidem, C. J. McMahon, R. R. Cohen, et al // J Am Soc Echocardiogr. - 2004. - Vol. 17. - P. 212-221.

12. Regression equations for calculation of $Z$ scores of cardiac structures in a large cohort of healthy infants, children, and adolescents: and echocardiographic study / Pettersen M., Du W., Skeens M. et al. // J Am Soc Echocardiogr. 2008. - № 21. - P. 922-934.

\title{
Criteria for diagnosis of the hypoplastic aortic arch in newborns and infants
}

\author{
Prokopovych L., Golovenko O., Perepeka I., Truba Y., Lazoryshynetz V. \\ National M. M. Amosov Institute of Cardiovascular Surgery National Academy of Medical Sciences of Ukraine (Kyiv)
}

To have a clear border between norm and pathology in order to determine in which cases the present hypoplasia is quite difficult. Therefore, from a practical point of view, the key issue is the selection of criteria on the basis of which one can speak of a clinical and prognostically significant hypoplasia of the aortic arch.

The review is devoted to the analysis of modern methods for determining the hypoplasia of the aortic arch and the results of surgical treatment of this pathology.

Key words: coarctation of the aorta, hypoplastic aortic arch, congenital heart diseases.

\section{Критерии постановки диагноза гипоплазии дуги аорты у новорожденных и младенцев}

\author{
Прокопович Л. М., Головенко А. С., Перепека И. А., Труба Я. П., Лазоришинец В. В. \\ ГУ «Национальный институт сердечно-сосудистой хирургии имени Н. М. Амосова НАМН» (Киев)
}

Провести четкую границу между нормой и патологией для того, чтобы определить, в каких случаях имеется настоящая гипоплазия дуги аорты, достаточно сложно. Поэтому с практической точки зрения важным вопросом является отбор критериев, на основании которых можно говорить о клинической и прогностически значимой гипоплазии дуги аорты. Обзор посвящен анализу современных методик определения гипоплазии дуги аорты и результатов хирургического лечения данной патологии.

Ключевые слова: коарктация аорты, гипоплазия дуги аорты, врожденные пороки сердиа. 